TID-4500, UC-4

Chemistry

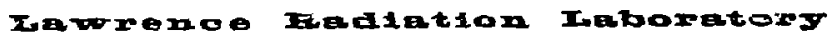

UHIYERSITY OF CALIFORHIA

IUERUARE

UCRL- 51006

\title{
ELECTRICAL RESISTANCE OF YTTERBIUM AS A FUNCTION OF TEMPERATURE AND PRESSURE
}

E. M. Lilley

D. R. Stephens

\author{
D. R. Stephens
}

This report was prepared as an tecount of work sponswed ty the United States Government. Nesithe the United State not the Jnited Stales Atomic Eneray Commixion, por eny of their tmployes, nor way of their contractors, subcontractars, $\infty$ their employen, makes any warraty, express or anplied, os assumes any legal liability or responsistity for the accurey, compietesest or uservises of any information, apparetus, product or prosess dicelosed, or reptesents that its use would not infringe privately owned rights. 


\section{Contents}

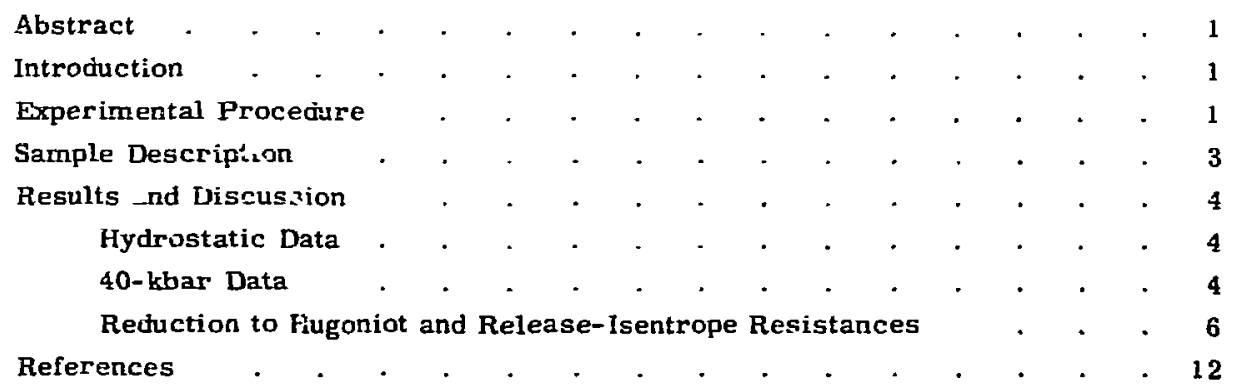




\title{
ELECTRICAL RESISTANCE OF YTTERBIUM AS A FUNCTION OF TEMPER.ATURE AND PRESSURE
}

\begin{abstract}
We have measured the piezoresistance of ytterbium from three sources at pressures tip to $40 \mathrm{kbar}$ and at terrperatures between 21 and $90^{\circ} \mathrm{C}$ under hydrostatic and quasi-hydrostatic conditions. From our data, irom calculations of Hugoniot state temperatures, and from the geometrical effect of plane strain on resistance, we also calculated the piezoresistance of ytterbium along the Hugoniot. Our computed results agree with the experimental Hugoniot data of Brown for the same samples to within 10\%. Considering the approximate calculations we used as well as possible errors in the experimental

measurements, this agreement is gocd.

Although resistance hysteresis upon unloading from the Hugoniot is observed in shock studies, we saw no measurable hysteresis at constant temperatures below the fcc-to-bcc transition. Only minor resistance hysteresis would be predicted on the basis of the temperature differences between the Hugoniot and the release states. The fcc-to-bcc transition in ytterbium, which occurs between 37 and $39 \mathrm{kbar}$ at room temperature, is predicted to occir between 34 and $35 \mathrm{kbar}$ along the Hugoniot as the transformation pressure decreases with increasing temperature.
\end{abstract}

\section{Introduction}

The electrical properties of ytterbium as a function of pressure have received considerable study, particularly at roorn temperature and lower. ${ }^{1-6}$ Since we were primarily interested in comparing our measurements with thoce obtained in shockwave studies, our measurements covered the expected temperature ranges of the Hugoniot and the isentropic release paths.
We used the four-lead electricalresistance system described hy Stromberg and Jura ${ }^{7}$ in a 40-kbar pistonand-cylinder system. We also used a four-lead electrical-resistance system in a hydrostatic system in conjunction with a resistance bridge and a null detector that was capable of resolving : $\times 10^{-4} \Omega$.

\section{Experimental Procedure}

Stromberg and Stephens ${ }^{1}$ obtained electrical-resistance data with a Bridgman anvil system that used the four-lead electrical-resistance system described 
by Stromberg and Jura. ${ }^{7}$ In our experiments with the piston-and-cylinder system, we used a similar setup. Figure 1 shows the details of our equipment. A constant current passed through the sample via the piston and the back-up block, and the voltage drop was measured independently by means of two copper leads. A calibrated strain-gage load ceill was used to measure the force on the piston, and a continuous record of resistance versus pressure was obtained with an $x-y$ recorder.

The pressure system was calibrated by means of a calibrated load cell and an S-R-4 box. The internal friction was abtained with the method described by Stephens, ${ }^{8}$ in which displacement is measured by a rectilinear potentiometer and applied force is measured by a load cell. These two s"gnals are displayed on an $x-y$ recorder while the pressure is increased and decreased. After the cell was pressed to the maximum pressure, we obtained a hysteresis loop of piston displacement versis pressurs, which established the friction described by Bridgman. 9

In our experiments with the hydrostatic system, the resistance was measured with a four-lead system that employed a Munller resisłance brídge and a null detector. The temperature was monitored witk a Chromel-Alumel thermocouple that was $0.6 \mathrm{~cm}$ from the ytlerbium wire. The pressure was measured with a 7-kbar Heise gage. Figure 2 shows the details

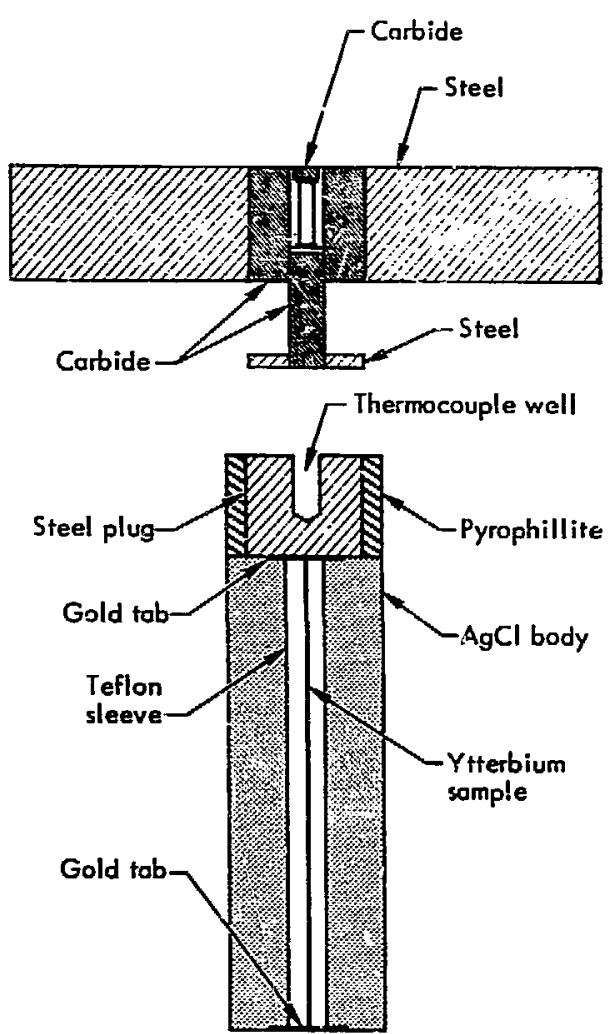

Fig. 1. Piston-and-cylinder system used to measure the electrical resistance $o_{i}^{*}$ ytterbium as a function of temperature and pressure.

of the setup. The pressure-transmitting medium was a diffusion-pumf oil.

In the hydrostatic system, both the pressures and the resistances are knows! to frithin $0.5 \%$. In the piston-and-cylinder system, the pressures are known to within $2 \%$ and the resistances to within $1 \%$. 


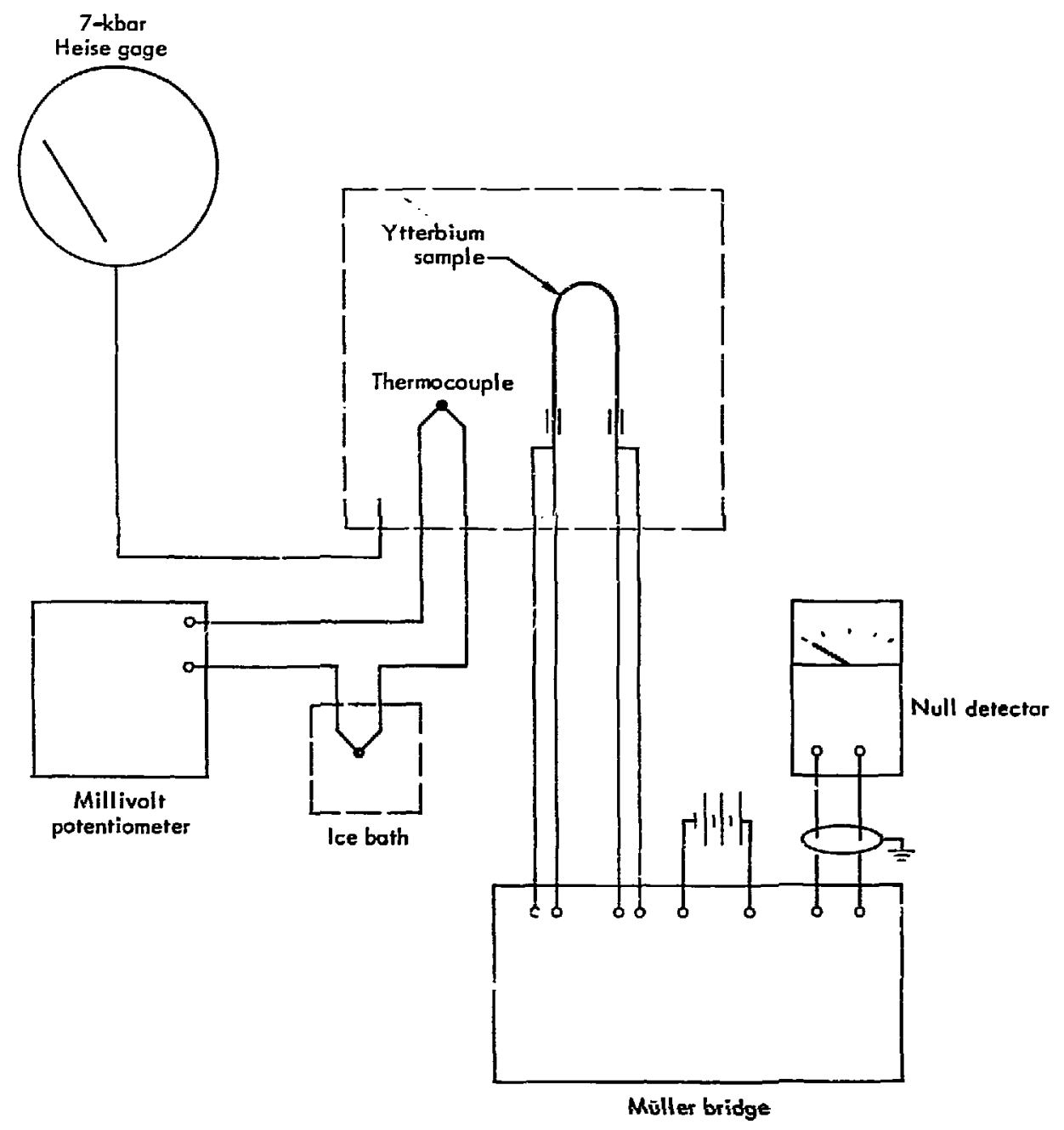

Fig. 2. Hydrostatic system used tc measure the electrical resistance of ytterbium as a function of temperature and pressure.

\section{Sample Description}

Samples were cut from a 0.001 -in.-thick foil obtained from Stephen R. Brown (designated "LRL ytterbium") and from a 0.003-in.- thick foil obtained from Harold
D. Stromberg ("Stromberg ytterbium"). Gold tabs were used on the ends of these samples to reduce contact resistance. A third sample censisted of a Stanford 
Research Institute ytterbium shock-wave grid ("SRI ytterbium") that was sent to us by Douglas D. Kecugh. The source of all three materials was the Research Chemicals Company, and the stated purity was 99.9 wt $^{2}$. Aninnic impurities such as oxygen usually are not included in such a statement of purity, and purity probably varies from one batch to another.

\section{Results and Discussion}

\section{HYDROSTATIC DATA}

The data we obtained from our hydrostatic study are summarized in Fig. 3. The behavior of the SRI ytterbium is somewhat different from that of the LRL ytterbium. Note that the resistance data for the LRL ytterbium upon loading and unloading are quite reproducible and show no pressure hysteresis.

The resistance of the LRL ytterbium can be expressed by

$$
\begin{aligned}
& \frac{R(P, T)-R_{0}}{R_{0}}=0.0016(T-21) \\
& +\left[0.0 \nmid j 16-3.3 \times 10^{-5}(T-21)\right] P \\
& +\left\{0.00233-5 \times 10^{-6}(T-21)\right\} P^{2},
\end{aligned}
$$

where $R(P, T)$ is the resistance at pressure $P$ (kbar) and temperature $T\left({ }^{\circ} \mathrm{C}\right)$ and $R_{0}$ is the resistance at 1 atm and $21^{\circ} \mathrm{C}$. This equation should be valid from roum temperature to $80^{\circ} \mathrm{C}$ and at pressures up to 7 kbar. Our experimental data are fitted by the equation to within $1 \%$.

\section{0-kbar DATA}

The data on relative resistance versus pressure that we obtained with the pistonand-cylinder system are shown in Figs. 4 and 5 and in Tables 1 and 2 . The resistance data in Fig. 4 are corrected to agree with the hydrostatic data at pressures of
5 kiar or less. The data in Fig. 5 show that ytterbium samples from different sources exhibit somewhat different piezoresistances.

At room temperature, the resistance of the ytterbium from all three sources ir ceases rapidly to about 7.5 times the 1 -atm resistance at an average pressure of $37 \mathrm{kbar}$, where a phas: transition takes place. The resistance then decreases rapidly to an $R / R_{0}$ of 0.8 at $43 \mathrm{kbar}$.

The transition pressures and the maximum resistances measured by static tecinniques at room temperature vary from one investigator to another, as is shown in Table 3. The presence of various amounts of impurities in the samples is believed to be one of the reasons for the differences. However, we believe that the pressures in our piston-and-cylinder system are closer to hydrostatic than those in the systems used by other workers, and since ytterbium is a semiconducto: at pressures above 10 to $14 \mathrm{kbar}$, some of the differences may be due to the well known sensitivity of semicouductors to nonhydrosiatic stresses.

Hall et al. ${ }^{10}$ have shown that the transition in ytterbium is from fcc to bcc. Our data as well as those of many other investigators show that there is considerable hysteresis in the transition at room temperaisere. Under increasing pressure the 


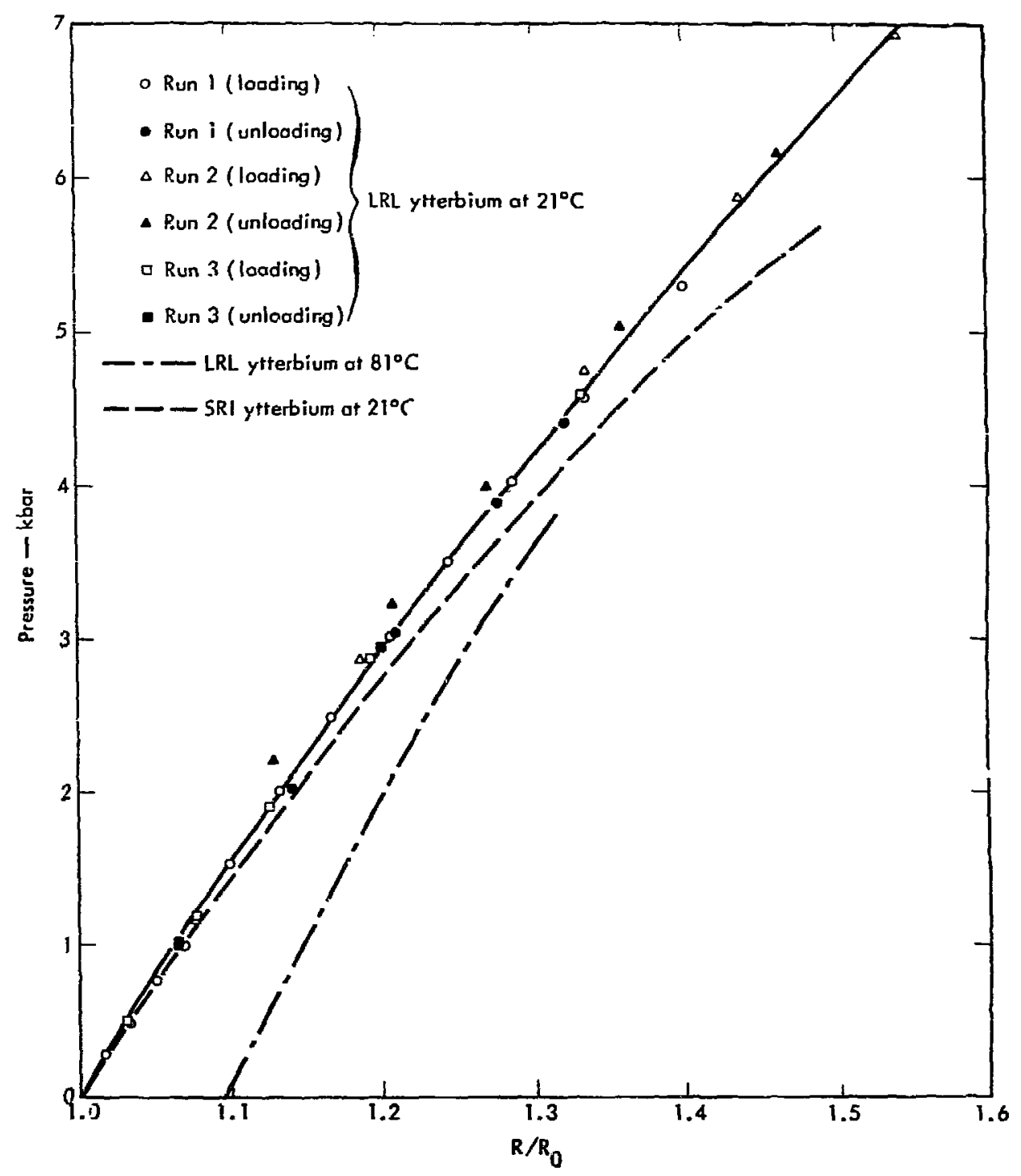

Fig. 3. Resistance of ytterbium as a function of temperature and hydrostatic pressure.

transition begins at $37 \mathrm{kbar}$ and ends at about $43 \mathrm{kbar}$, while under decreasing pressure the reverse transition begins at $16 \mathrm{kbar}$ and ends at $10 \mathrm{kbar}$. At higher temperatures, however, there is somewhat less hysteresis. At $90^{\circ} \mathrm{C}$. the resistance rises to about 6 times the 1-atm resistance at $34.5 \mathrm{kbar}$, then decreases 


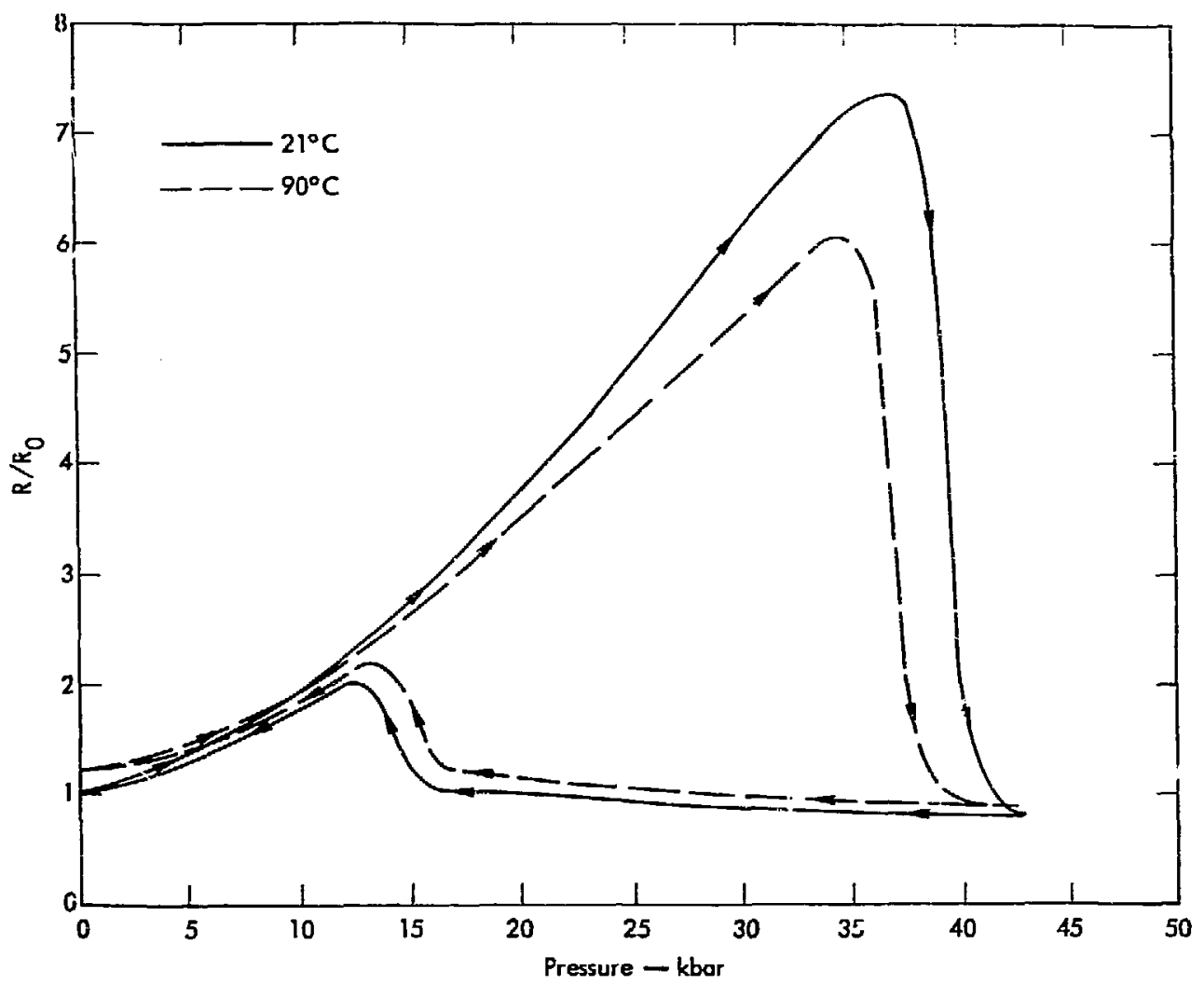

Fig. 4. Resistance of LRL ytterbium as a function of temperature and pressure.

rapidly to 0.8 times the 1 -ditm resistance at $41 \mathrm{kbar}$. Under decreasing pressure, the resistance remains nearly constant until about $17 \mathrm{kbar}$, where the resistance increases. At ahout $13 \mathrm{kbar}$, the resistance reaches a maximum, then decreases to the 1-atm value.

Thus, the fcc-to-bec transition is hysteretic, and hence resistance data at pressures above the transition are a'so hysteretic. However, we have shown that at constant iemperatures there is no resistance hysteresis at pressures within the stability field of the fcc phase.

\section{REDUCTION TO HUGONIOT AND} RELEASE-ISENTROPE RESISTANCES

In order to compare the above data to resistances obtained by shock-w.ive techniques, we must first calculate the temperatures due to shock loading and isentropic release and convert them to $R(P, T$ ) Then we must take irio account the geometrical effect of plane-strain loaring (see Ref, 11).

The temperatures calculated according to the method of Walsh and Christian ${ }^{12}$ are shown in Fig. 6, where the temperatures along the Hugoniot and several 


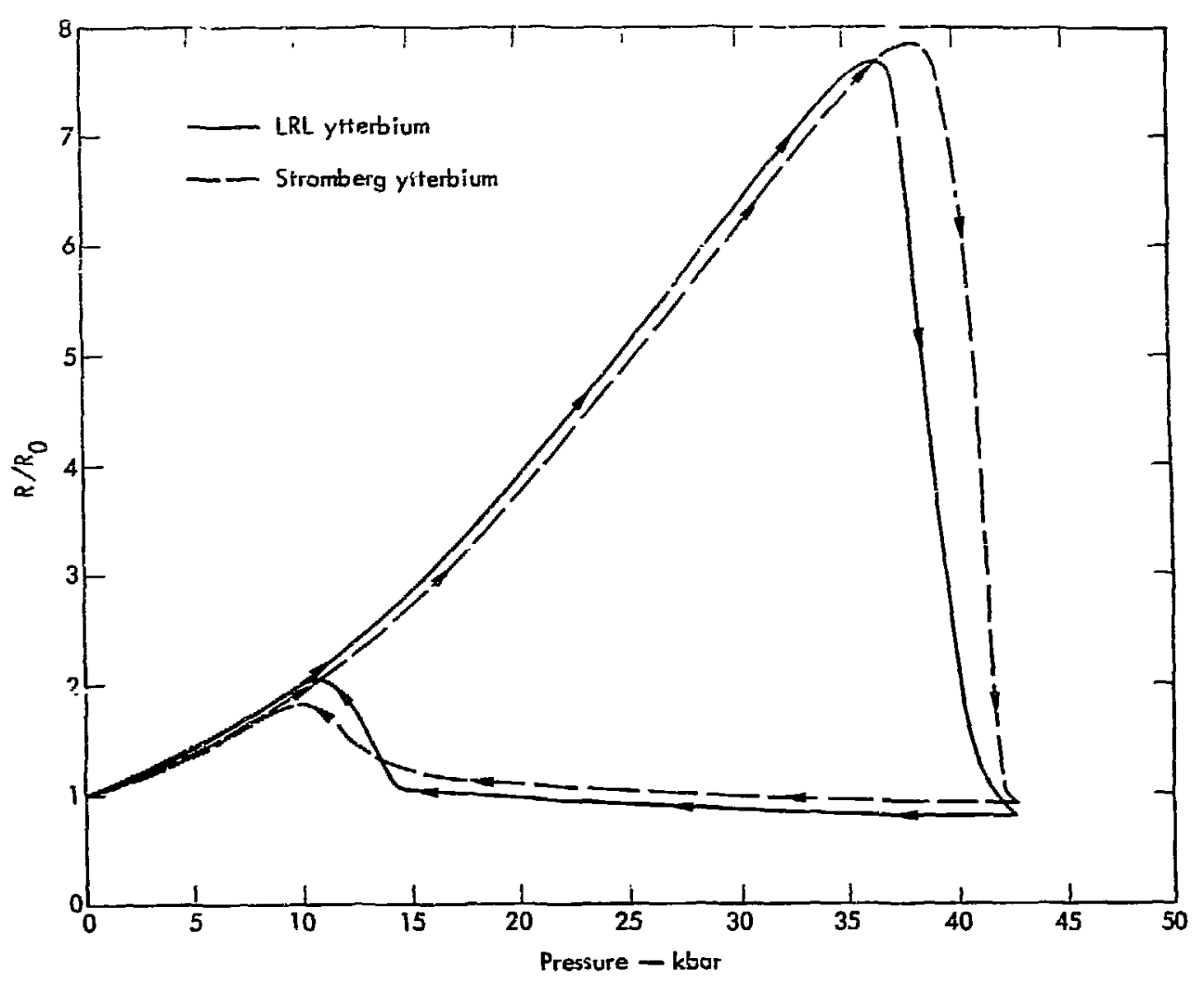

Fig. 5. Resiztance of ytterbium at $21^{\circ} \mathrm{C}$ as a function of pressure.

Table 1. Resistance versus pressure of LRL ytterbium at $\mathrm{z}^{\circ}{ }^{\circ} \mathrm{C}$.

\begin{tabular}{cccc}
\hline $\begin{array}{c}\text { Pressure } \\
\text { (kbar) }\end{array}$ & $\mathrm{k} / \mathbf{R}_{\mathbf{0}}$ & $\begin{array}{c}\text { Pressure } \\
\text { (kbar) }\end{array}$ & $\mathbf{R} / \mathbf{R}_{\mathbf{0}}$ \\
\hline 0 & 1.000 & 42.5 & 0.780 \\
5 & 1.366 & 40 & 0.80 \\
10 & 1.94 & 30 & 0.87 \\
15 & 2.75 & 20 & 0.98 \\
20 & 3.74 & 15.8 & 1.08 \\
25 & 4.87 & 14 & 1.62 \\
30 & 6.10 & 13.5 & 2.00 \\
35 & 7.16 & 10 & 1.77 \\
36.7 & 7.38 & 5 & 1.27 \\
39.5 & 3.70 & 0 & 1.00 \\
\hline
\end{tabular}

Table 2. Resistance versus pressure of LRL ytterbium at $90^{\circ} \mathrm{C}$.

\begin{tabular}{cccc}
\hline $\begin{array}{c}\text { Pressure } \\
\text { (kbar) }\end{array}$ & $R / R_{G}{ }^{a}$ & $\begin{array}{c}\text { Pressure } \\
\text { (kbar) }\end{array}$ & $R / R_{0}{ }^{a}$ \\
\hline 0 & 1.22 & 42.5 & 0.880 \\
5 & 1.457 & 40 & 0.90 \\
10 & 1.93 & 30 & 0.98 \\
15 & 2.63 & 20 & 1.13 \\
20 & 3.49 & 16.5 & 1.24 \\
25 & 4.39 & 13.5 & 2.18 \\
30 & 5.31 & 10 & 1.85 \\
34.6 & 6.05 & 5 & $i .39$ \\
36.5 & 4.76 & 0 & 1.22 \\
37 & 3.20 & & \\
\hline a Normalized to roon temperature.
\end{tabular}


Table 3. Transition pressures and maximum resistances of yttertium at room temperałure as measured by various investigators.

\begin{tabular}{|c|c|c|}
\hline Investigator & $\begin{array}{c}\text { Transition } \\
\text { pressure } \\
\text { (kbar) }\end{array}$ & $\begin{array}{l}\text { Maximum } \\
\text { resistance } \\
\left(R_{/} / R_{0}\right)\end{array}$ \\
\hline $\begin{array}{l}\text { Stromberg } \\
\text { and Stephens }\end{array}$ & 39 & 23 \\
\hline Bridgman ${ }^{2}$ & $41^{2}$ & 13 \\
\hline $\begin{array}{c}\text { Stager and } \\
\text { Drickamer }\end{array}$ & 38 & $\sim 6$ \\
\hline Souers and Jura 4 & 40 & 11 \\
\hline MeWhan et al. ${ }^{5}$ & 40 & $\sim 11$ \\
\hline King and Harris ${ }^{6}$ & 39 & 8.5 \\
\hline This work & 37 & 7.4 \\
\hline
\end{tabular}

relcase siates (which are assumed to be isentropic) are shown. The pressureversus-volume data were taken from Stephens, ${ }^{8}$ as was the initial compressibility. The heat capacity and the thermal expansion wsre taken trom Gschneidner. ${ }^{13}$ The Gruneisen parameter, $\gamma=(V a) /\left(\beta C_{v}\right)$, was then 1.10 , where $V$ is the volume, $\alpha$ is the volume coefficient of thermal expansion, $B$ is the compressibility at a constant temperature, and $C_{V}$ is the sperific heat at a constant voiume. Tabla 4 shows piezoresistances alung the Hugoniot and rele ase states as computed from our $R(P, T)$ data and the calculated temperatures.

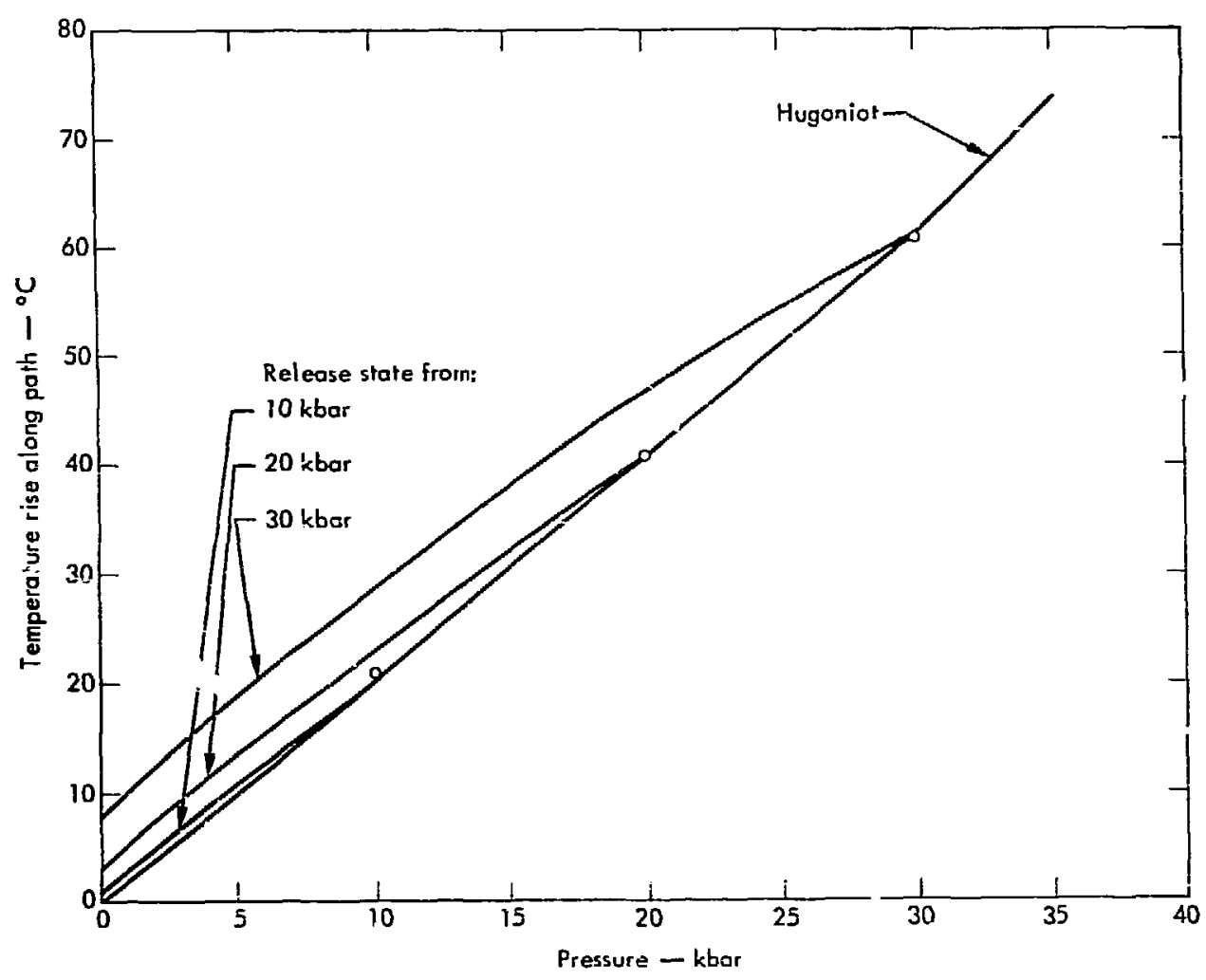

Fig. 6. Temperature rise as a function of pressure along the Hugoniot and release paths of ytterbium. 
Table 5. Predicted $R / R_{0}$ values for Hugoniot and release states after corrections for temperature and geometrical effects.

\begin{tabular}{ccccc}
\hline $\begin{array}{c}\text { Pressure } \\
(\mathrm{kbar})\end{array}$ & Hugoniot & $\begin{array}{c}\text { Release from } \\
10 \mathrm{kbar}\end{array}$ & $\begin{array}{c}\text { Release from } \\
20 \mathrm{kbar}\end{array}$ & $\begin{array}{c}\text { Release from } \\
30 \mathrm{kbar}\end{array}$ \\
\hline 0 & 1.000 & 1.002 & 1.005 & 1.013 \\
5 & 1.409 & 1.411 & 1.413 & 1.421 \\
10 & 2.01 & 2.01 & 2.01 & 2.01 \\
15 & 2.87 & - & 2.86 & 2.85 \\
20 & 3.88 & - & 3.88 & 3.86 \\
25 & 4.98 & - & - & 4.98 \\
30 & 5.99 & - & - & 5.99 \\
34.5 & 6.71 & - & - & - \\
\hline
\end{tabular}

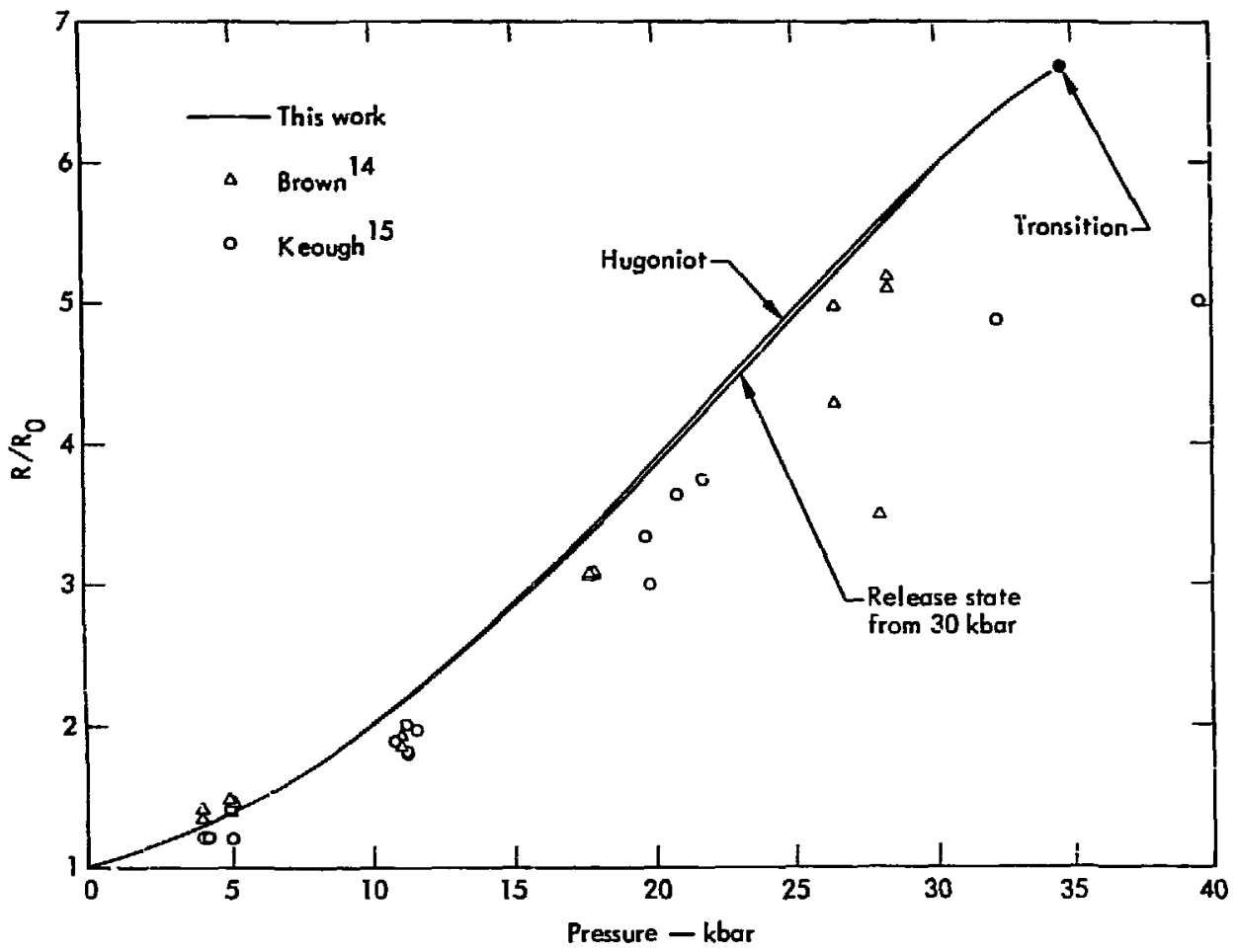

Fig. 7. Hugoniot piezoresistance of ytterbium.

effects. The fact that ytterbium's temperature coefficient of resistance is posi- tive to 10 to $14 \mathrm{kbar}$ and is negative at high pressures leads to little difference 
in the resistances upon shock loading and isentropic release.

Note that the resistance curve in Fig. 7 terminates at 34.5 kbar. At this point, we calculate that the $P, T$ trajectory of the Hugoniot intersects the fec-to-bce transition, and thus the maximum resistance occurs at 34.5 kbar. Note also that our predicted piezoresistance along the Hugoniot agrees with most of Brown's data to within $10 \%$. In this case, howerer, we are comparing the same ytterbium. Keough's data for ytterbium from a different batch but Irom the same company indicate lower resistances at the same pressure than either our predicrion or Brown's data.

The agreement of our prediction to within $10 \%$ of the experimental data is perhaps all that can be expected. There are errors in the Hugoniot measurements and in our $R(P, T) / R_{0}$ measurements. Certainly, there are errors in the calculation of the Hugoniot temperatures, and there could be as much as a $20 \%$ error in $\Delta T$. In addition, errors in the pressure-versusvolume data are reflected in the $\left(v / v_{0}\right)^{-2 / 3}$ term in the calculated geometry effect. Finally, and perhaps most importantly, we have not considered the well known fact that the resistance of semiconductors (and ytterbium is a semiconductor above 10 to 14 kbar) is sensitive to deviatoric stresses as well as to pressure and temperature. We conclude that the experimental Hugoniot measurements ${ }^{14}$ agree reasonably well with the calculated Hugoniot based on our static $\mathbf{R}(P, T)$ data and the plane-strin factor. 


\section{References}

1. H. D. Stromberg and D. R. Stephens, J. Phys. Chem. Solids 25, 1015 (1964).

2. P.W. Bridgman, Proc. Am. Acad. Arts Sci. 83, 1 (1954).

3. R. A. Stager and H.G. Drickamer, Science 139, 1284 (1563).

4. P.C. Souers and G. Jura, Science 140, 481 (1963).

5. D. B. McWhan, T.M. Rice, and P.H. Schmidt, Phys, Rev. 177, 1063 (1969).

6. E. King and I. R. Harris, J. Less-Common Metals 20, 237 (197C).

t. H. Stromber: and G. Jura, Science 138, 1344 (1962).

B. D. R. Stephens, J. Fhys. Chem. Solids 25, 423 (1964).

9. P.W. Bridgman, Proc. Am. Acad. Arts Sci. 74, 21 (1940).

10. H. T. Hall, J. D. Barnett, and L. Merrill, Science 139, 111 (1963).

11. D. D. Keuugh, R. F. Williams, and R.A. Pasternak, Piezoresistive Shock Transjucer Study Using Lithium, Stanforo Research Institute, Rept. PGD-6403 (1968).

12. J. M. Walsh and R. H. Christian, Phys. Rey. 97, 1544 (1955).

13. K. A. Gschileidner Jr., "Physical Properties and Interrelationships of Metallic and Semimetallic Elements," in Solid State Physics: Advances in Research and Applications, F. Seitz and D. Turnbull, Eds. (Academic Press, New York, 1964), vol. 16 .

14. S. R. Brown, Development of Piezoresistive Stress-History Gages, Lawrence Radiation Laboratory, Livermore, Memo DET 70-48 (1970).

15. D. D. Keough, Development of a High-Sensitivity PiezGresistive Shock Transducer for the Low Kilobar Range, Stanford Research Institute, Rept. DASA-2508 (1970). 
How $7 y^{2}$
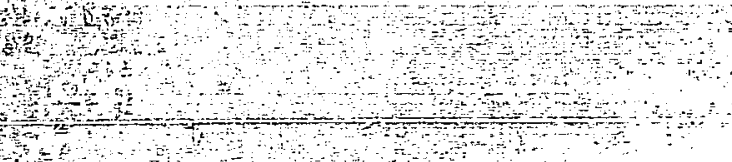

Printed in USA. Available from the National Technical Information Center, National Bureau of Standards,

U. S. Department of Commerce, Springfield, Virginia 22151 Price: Printed Copy $\$ 3.01$; Microfiche $\$ 0.65$. 